\title{
Denpasar City Disability Policy Advocacy Through The Non-Governmental Organization (Ngo) Care About Disability
}

\author{
Komang Ema Marsitadewi ${ }^{1}$, I Gusti Agung Ayu Yuliartika Dewi ${ }^{2}$, Lilik Antarini ${ }^{3}$ \\ \{emarsitadewi@gmail.com\} \\ Universitas Warmadewa, Bali, Denpasar ${ }^{123}$
}

\begin{abstract}
This minority of disability affects the fulfillment of the needs and rights of persons with disability by the Government. The needs of persons with disability are often not seen by the Government. Whereas persons with disability have the right to fulfillment and equal rights with society in General. In the city of Denpasar, which is the administrative center of the region of Bali himself was, the needs of persons with disability is not fulfilled to the maximum. The needs of persons with disability rights up to government level is inseparable from the existence of non-governmental organizations (NGOs). NGO nongovernmental institution has great influence in a decision public. Nongovernmental organizations (NGOs) Concerned with Disability can help so that the needs and rights of persons with disability have their right in Government policy through the stages of the public policy advocacy. By using qualitative research methods, the conclusion that Care Disability NGOs have been able to be part of the policy advocacy disability. It's just a policy that successfully produced the present province of new haven't touched the scope of Denpasar.
\end{abstract}

Keywords: Advocacy, Regulation, Disabillity.

\section{Introduction}

In doing the fulfillment of the needs of the community, the community should be viewed as customer and the government as provider. This is done to motivate the government to fulfill the community needs. It doesn't only consicer community as customer, the important point to fulfill the community needs, the government have to be able to fulfill the needs through the regulation that can distribute all of the community needs without discriminating based on class, ethnic, race, and group.

Making a regulation that can accommodate all of community without discriminate each other is a government responsibility. Wether central government or local government. Denpasar government is one of governments in Indonesia. Denpasar government has responsibility to make regulation that can accommodate all of community needs, like community that has special needs which is known as disability.

Disability or disabilities are also often referred to as society that is diffable have differences with other people in General. Disabilities in the definition of disability from the WHO, disability is a condition that causes a disturbance in one's relationship with the environment [1]. There is interference on the disability renders diffable "typical" than society in General. But basically, people with disability is the same individual with other normal 
society, it just requires a different treatment [2]. But in fact, persons with disability are often grouped into different communities and then becoming the minority in society.

Reversed the position of the persons with disability as minorities and marginalized, the percentage of the number of persons with disability in fact happens vice versa. Percentage of the number of persons with disability in Indonesia increasingly has increased. This is indicated on the data in the Data Center and information of the Ministry of Health of INDONESIA. Percentage of persons with disability Indonesia in 2003 that just being on a percentage of the 0.69 , increased until 2012 become 2.45 [1] . In the span of nine years, Indonesia is experiencing a sharp increasement. This needs to be taken care of by the Government, that people with disabilities disability cannot be considered a mere minority groups. But the society should get the fulfillment of rights and the same attention from Governments across Indonesia.

If the percentage of persons with disability in Indonesia are on the value 2.45 which is show the increasing percentage 1.53 from 2009 . Bali province has disability percentage of 2.37. For detail it can be shown in the table 1 .

Table 1. The Percentage of Disability Based on Susenas Data 2012 [1]

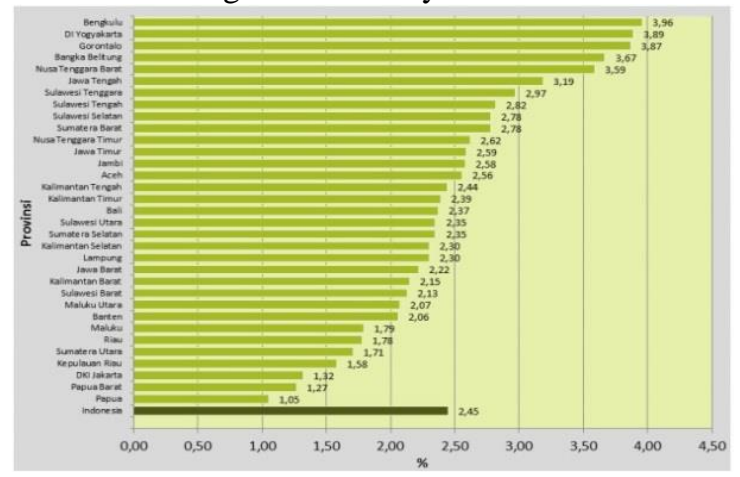

In table 1 it can be seen that the average percentage of the persons with disability of Indonesia 2.45. Bali has the percentage of 2.37. if it is analyzed in detail, percentage of Bali is 2.37 , it is closed to the Indonesian's average value. This should be the marker for the Bali Government that there is a number of people with disability are virtually on par with the average persons with disability Idonesia. it means that, there are a number of people with a disability is large enough to be aware of and be given the same rights fulfillment. People with disability can no longer be seen as a marginalized community groups and minority.

The position of persons with disability are marginalized can be one of the factors that caused the weakness of disability rights fulfilment by Government. People with disability have no power in presenting the needs of persons with disability itself, when the position or the position just have been isolate in the community. Thus, persons with disability requiring the other party to help strengthen the position of persons with disability in the social community so that the needs of persons with disability can be accomodate in government policy.

Within the framework of public policy, there are public policy actors who have the power in the public policy process. One of them is the interest groups. Interest groups are groups of people who voiced particular interests that benefit the group or society at large. Non-governmental organization Care Disability form from interest groups that have the power 
to help people with disability in order that the needs and rights of persons with disability in disability policy.

Non-governmental organizations (NGOs) can help disability so that the needs and rights of persons with disability in terakomodasi Government policy through the stages of the public policy advocacy. Which policy advocacy is advocacy efforts (escort) programmatically against the plan of attitudes, action plan or plan decisions, plan program or regulatory plan designed by the Government to do or not to do so in accordance with the interests of the community. [3] Policy advocacy by non-governmental organizations (NGOs) Care Disability will be able to encourage the fulfilment of the rights of persons with disability policy.

\section{Methodology}

This research is qualitative research, which is in this research involved twelve 12 informant and supported by documentation as an instrument of data collection. The analisis data use triangulation data to decrease the refraction of the research.

\section{Results and Discussion}

\subsection{Advocacy for Disability}

In 1950-1980 looking a regulation process through administrative perspective. In this perspective, the process of policy formulation up to range from evaluation seen linearly as the mechanism process. Because it is in the realm of public administration, the policy is seen as a process of internal government authority, so that community participation is seen as a formality only to increase the legitimacy of these policies. [4] However, in the era of reform as currently, the policy process is no longer seen simply as a linear process. The society has now become part of the policy process. Likewise with people with disability. In theory, people with disability is mandatory included into the process of policies, particularly the policies that produced to answer the needs of persons with disability.

Change the view related policy processes that shaped the policy process include the society in this article i.e. persons with disability have not been fully understood by the persons with disability itself. It was revealed by the Informant DN 1.

"Oh kalo itu saya belum pernah dik, kebetulan untuk organisasi saat rapat ada saja yang mengusulkan tetapi saya ya hanya nurut-nurut saja.Selain itu ya karena saya tidak berani juga." [5]

"Oh I never done it yet, by chance, there is a suggestion in the community meeting but $i$ only agree with that. Beside that, I don't have any courage."

Based on the informant DN 1, it can be seen that a disability still "afraid" conveying their needs ti the government, even DN 1 is a member of organization. Not only "afraid" DN 1 seen the advocacy like a demonstracy.

There is a minimum knowledge about the regulation process is not linear to the government through regulation advocacy. Informant DN 2 have same perception with DN 1.

"Ingin sih dik tapi ya saya males karena menurut saya itu buang-buang waktu karena apa? kita gerak-gerak menyampaikan aspirasi dijalan menyuarakan tapi akhirnya pekerjaan 
kita yang harus dijalani tertunda dan bahkan aspirasi itu pun belum tentu diwujudkan dengan cepat jadi ya menurut saya fokus bekerja saja lah."

"yes, but iam not interesting and it wasting time because of what? We shout to convey our opinion in the road but at last our job is delayed and our opinion also can not become reality yet. So focus on the job." [6]

Informant DN 2 corroborating that persons with disability still consider policy advocacy as a demonstration conducted by the community in voicing the desires or needs. Even though the policy advocacy and demonstration are two different things. Advocating more leads as a media to realize the goal of a more organized activities.

Through Infoman DN 2, can be studied also in addition to assume the same advocacy with demonstration, persons with disability are still considered that the response of the Government against persons with disability is still very low. Any similar things expressed by Informants DD 3.

"Yaa males gak didenger gitulah. ya kalo suara berbanyak dari organisasi terbantulah sedikitlah.”

"I don't have any concern about it anymore, because they doesn't listen. Yaa when there is more voices from the organization, it is helping."

DN 2 opinions in accordance with the opinion delivered by the DD 3. In the perspective of disability, regardless of the form of the activities carried out by disability not responded well by the Government. This causes the disability does not want to do any form of necessity in conveying activities. Basically through this perspective, the Government can restructure themselves so that persons with disability more cooperative in the process of policy especially with disabilities disability policy.

Reversed the opinion of the negative response of the Government, there is positive information from Informants DD 3. Informant DD 3 has been noticed in the submission of opinions in order to be carried to the Government should through the organization. This in fact is the first step of a policy advocacy. In the process of policy advocacy, there is the process of the formation of the coalition. With sign in or join in an organization, it is indirectly build a coalition. The Coalition's future that will move the designing tactics in order to make advocacy received or until the purpose of advocacy.

Organizations are important to the delivery of the need felt by the Informant DN 2.

"Saya memang ikut organisasi tapi untuk mengajukan itu saya belum pernah karena walaupun saya merasa peran pemerintah belum maksimal tapi ya saya merasa sudah pernah dibantu ya sudahlah.Tapi untuk di organisai ada beberapa temen yang dipilih oleh pemerintah untuk itu." [6]

"I am the member of the organization but for propose that I never done it yet, because I feel government role is not maximum yet but I felt I have got any help so nevermind. In organization there are several friends which is chosen for that. 
Although the Informant DN 2 have never takes part directly into policy advocacy activities, but undertook to enter into the Organization was already a good step. Entry into the Organization of the unconscious will directly voice their need of him with other members. Other members who did have a part in policy advocacy shall convey the needs of the other members. This is of great help not only persons with disability unless the Government in making policies that pro to disability.

Non-governmental organization (NGO) care about Disability in this case i.e. Puspadi Bali admitted that people with disability are currently better able to convey t needs. People with disability have discovered the early attainment of the needs of persons with disability i.e. through yourself by going into the organization or participating in the activities of the Government.

"iyaa mereka sekarang sudah lebih aktif. Tahu bahwa bukan lagi penyandang disabilitas atau bukan.Melainkan pemenuhan hak asasi manusia. Banyak penyandang disabilitas sekarang berkegiatan di organisasi-organisasi. " [7]

"Yes they are now more active. Know that is no longer disabled, disability or not. But the fulfillment of human rights. Many people with disability are now actively taking part in organizations."

From the statement of the NGO 2 corroborating this Informant that there has been a mindset of persons with disability. The level of awareness that persons with disability have the same rights with other growing communities. It is so petrified primarily organizations or nongovernmental organizations engaged in the field of policy advocacy such as Puspadi.

Through interrelated information between informants can be drawn the conclusion that persons with disability is still considered the same policy advocacy with demonstration. So that persons with disability advocacy fear. Because persons with disability advocacy must be the same as the demonstration is an activity that is likely to be against the Government. Even though the policy advocacy and demostracy are two different things.

Not only can you draw the conclusion that people with disability are still considered the same policy advocacy with demonstration, positive thing that can be seen from the above information that not a few persons with a disability enter into the organization. Although not included in advocacy but this shows a good step. Through the initial process of policy advocacy organization performed and designed.

\subsection{NGO as A Mediator Regulation Advocacy}

Bali is one of the Puspadi Foundation under the Annika Linden Centre and also a foundation that has a purpose one of them fighting for the rights of persons with disability. Puspadi Bali in general exist, to help people who have a physical disability to access rehabilitation services so that persons with disability can act as a productive citizen. Services provided by Puspadi Bali can be seen in the figure 1 . 
Figure 1. Puspadi’s Service Graphic 2017

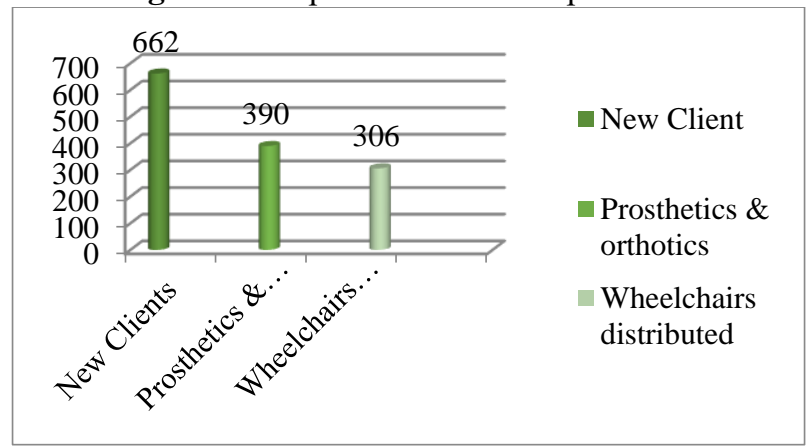

Source: prepared from Inspirasia Annual Magazine: 2018 Growth \& Impact Annika Linden Centre 5th Anniversary

In the image above, it can be seen that the Puspadi Bali provides some services to the disabled, disability, among others, the giving of false legs and wheelchair disabilities disability according to the needs of each.

"program Puspadi banyak. Memberikan alat bantu kaki palsu dan kursi roda secara gratis bagi temen-temen yang kurang mampu. Bayangkan kalo kaki palsu dirumah sakit itu bisa nyampe 7 juta.Tapi kalo disini mereka bisa dapet gratis jika mereka tidak mampu.Kalau mereka maтри itu ada namanya donasi.Kontribusilah.Pembuatannya langsung disini dengan tenag ahli pembuat kaki palsu dari JSPO dari Jakarta. Lulusannya memang khusus untu kaki palsu dan alat bantu." [8]

"puspadi has a lot of programs. Give a fake leg AIDS and wheelchairs free of charge for allegedly less capable. Imagine if a false foot at home sick it could reach 7 million. But here they can dapet free if they can't afford. If they can afford it there his name donate. Making straight here with a false leg maker experts from JSPO from Jakarta."

The granting of a wheelchair and prosthetic legs that are on the Puspadi is apart from the donation, is also the result of cross-subsidies between friends that can't afford with which indeed can afford. The granting of a wheelchair and prosthetic leg also in Puspadi Bali is not an arbitrary program. It is implied from the wheelchair and the making of false legs according to the size of each kedisabilitasan. It is supported by the existence of professional personnel in their jobs. 
Figure 2. Fake leg process by the expert

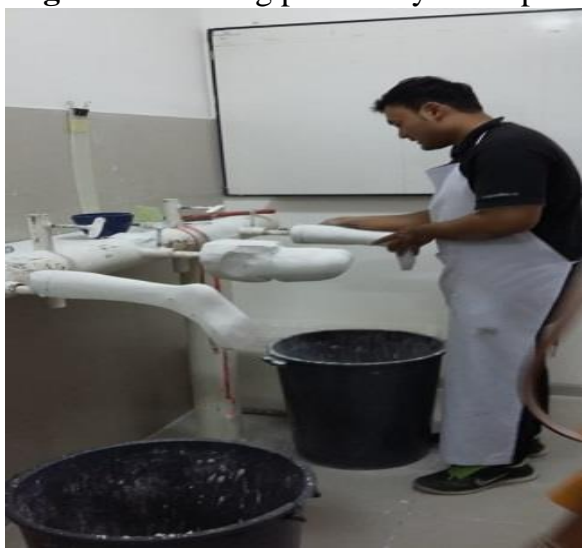

Source: Researcher private document

The initial process of measuring and printing false legs done by experts. So that persons with disability will not feel uncomfortable when using it. This is also the excess of Puspadi. Not only because it is carried out by experts in their field, Puspadi Bali also employs persons with disability in the process of making a fake leg. Of the total staff is there in Puspadi Bali, $60 \%$ were persons with disability. It is as a form of support for persons with disabilities that the disability have the same rights with other general public.

Puspadi Bali itself, founded in 1999 which is a non-governmental local community who are committed to improving the lives of people with physical disability across Eastern Indonesia and Bali, as well as striving towards society an inclusive where people with disabilities disability are treated equally and given the same opportunity as everyone else. One form of activity other than the giving of false legs and wheelchair access, activities performed by Puspadi Bali in the fight for the rights of persons with disability is to initiate and participate fill out related content of the existence of a the umbrella law for persons with disability. It's just that it is preceded by the participation of Informants in charging content umbrella law at the national level.

"Sebenarnya sejak 2002, saya terlibat dalam kebijakan publik yang berkait dengan disabilitas.terlibat juga dengan MDG's. Disitu pertama kali yang menyuarakan tentang disabilitas.waktu itu isinya tentang kemiskinan sebenarnya. Tapi saya dengan lantang bilang waktu itu jangan bicara tentang kemiskinan kalau melupakan disabilitas. Jadi kan $80 \%$ orang miskin itu disabilitas. Jadi saya sebagai pribadi, sebagai lembaga, semabagi Puspadi Bali menginisiasi disabilitas di tingkat nasional.Mulai 2013 tahun berikutya kita menyusun undang-undang yang dikenal sekarang undang-undang disabilitas.Undang-Undang no 8 tahun 2018. Saya termasuk didalamnya jadi masuk mengisi-ngisi kontennya itu." [7]

"In fact since 2002, I am involved in public policies that relate to disability. involved also with MDG's. There was first the voice of disability. the time the contents of actual poverty. But I say aloud that time don't talk about poverty if forget about disability. So $80 \%$ right poor people that disability. So I am as a person, as an institution, as Bali Puspadi initiates the disability at the national level. In the year 2013 we draw up legislation which is now known disability legislation. Law No. 8 year 2018. I included in it so it fills the contents of it."

Informant 2 explain that disability becomes an important thing to be resolved. It strongly influenced the change of State of a region or country. Because it is based on interviews, $80 \%$ of people with disabilities disability is poor. Therefore, when the Government of mengingkin 
settlement for nurturing associated poverty. The Government should not forget about the existence of persons with disability. This is emphasized by Informants 2 .

Not only do disability being completed, it is important to quote from the interview above explains that Infoman 2 have been struggling with disabilities disability rights fulfillment voiced at the national level. The existence of the present national law umbrella will greatly influence the course of the protection and fulfillment of the rights of persons with disability in each area. The existence of the umbrella national law related disability alone would be very helpful.

Through the involvement of Informant 2 personally in the preparation of related disability legislation which was passed in the year 2016 i.e. Law No. 8 year 2016 about persons with Disability are very helpful born Bali province Area Regulation No. 9 The year 2015 on the protection of the rights of persons with Disability and fulfillment.

"lalu saya berpikir dong.. Bali kita bisa lakukan apa. Kami menyusun perda.Perda No 9 tahun 2015. Saya dengan temen-temen DPO yang ada di Bali menyusun itu selama tiga tahun. Jadi Puspadi Bali, saya sebagai koordinator meng-lead workshop sampai menyusun memberikan kontennya, sampai memperjuangkan disahkan .

"then I thought, we can do what Bali. We compile local reguation. local regulation No. 9 2015. I and friends in DPO in Bali compile it for three years. So Puspadi, I am as a coordinator to lead workshop to compile its content, giving up the fight for legalized"

Bali Puspadi struggles in start, putting together, fight for legality of applicable local No. 9 years 2015 about persons with Disability being one of advocacy actions in the form of existence of an umbrella law for the disabled, disability level area the province.

For Denpasar, Bali Puspadi has not so far do the initiation or the preparation of academic texts that would later become a draft local regulations. This matter can not be forced. As the NGOs or governmental agencies not authorized Puspadi Bali in control or whether there is a legal umbrella. It must be realized by the Government itself by looking at the leader's desire to manifest.

Produce a law like Rule the area of Bali No 9 Year 2015 on the protection of the rights of persons with Disability and the fulfilment of which was initiated by Pupadi Bali spent more than two years. So there is or whether a law was not merely a practical thing or instant. Many factors influence therein as of the time and the desire of the leadership of a very decisive factor becomes.

Haven't stepped on the initiation of academic texts as the basis of legal disability at the city level, does not mean Puspadi Bali did not do any thing related disabilities disability. Puspadi Bali recently on stage doing workshops and meeting in order to increase awareness of the existence of persons with disability will be the general public.

"Kami melakukan workshop-workshop tentang penyadaran tentang disabilitas.jadi kami secara rutin adakan HDI, Hari Disabilitas Internasional jadi kita adakan. itu diadakan tidak ekslusif tapi inklusif. Bagaimana melibatkan pemerintah, masyarakat .termasuk tahun ini nanti 14,15 merayakan HDI salah satu itu untuk meningkatkan kesadaran tentang penyandang disbailitas. " [7]

"We did a workshop about awareness about disability. so we routinely conduct HDI International Disability Day, so we have put out. It was held not exclusive but inclusive. How to involve the Government, including the community. this year later 14.15 celebrate HDI one of it to raise awareness about disbaility."

Excerpts from the interview above, it can be seen how Puspadi Bali move Government and public take part in the International Disability Day (HDI). This is intended so that through the participation of the Government and the community in the HDI, the Government and 
society were determined to provide equality for persons with disability. Encourage awareness that persons with disability the same as other public societies.

The grant of a meeting or workshop related to the disability community and undertook to involve the Government and the community in the HDI is reminiscent of how the stages of carrying out advocacy.

The granting of a meeting/workshop conducted by Puspadi Bali and also involve the Government and society in the great day for persons with disability when analyzed using flow advocacy in the image above, has indirectly run the Groove in advocacy. Puspadi Bali are currently in the stage of building a coalition. It can be said in the stages of building a coalition because unconsciously by involving Governments and communities into the activities of the disability, it can build the same perception will disability. When perceptions have equated it will automatically make it easier to build a coalition that would later support in realizing the goals/objectives.

Puspadi Bali as a non-governmental organization that not only focused on services and rehabilitation of persons with disability, but also on policy advocacy and empowerment demands Puspadi Bali to continue doing the steps advocacy. Puspadi Bali located in Denpasar City does not become a barrier to continue to improve the granting of protection and fulfilment of the rights of persons with disability. Policy advocacy carried out by Puspadi Bali after successfully initializing the inception of local regulations of the province of Bali No 9 Year 2015 on the protection of the rights of the disabled and Disability namely produces academic manuscript has now been at the stage of drafting the Regulations the Governor in Buleleng Regency. The initiation performed by Puspadi Bali will legal disability Buleleng Regency also is not a step that Flash and instant.

"yaa kita untuk menghasilkan naskah akademik saja harus banyak sekali diskusi, melakukan FGD dan semacamnya. Agar naskah akademik yang nantinya menjadi peraturan daerah mempunya kekuatan yang bisa menjawab apa kebutuhan penyandang disabilitas disana. Jadi gak kayak peraturan ompong gak ada giginya.” [7]

"We generate script academic course must be a great many discussions, do the FGD and such. In order for the academic manuscript later became the regulatory area had the strength that could answer what the needs of persons with disability. So not like a toothless regulation do not have his teeth."

Not denied that there are often local regulations which did not really answer the needs of community needs. to learn from things that Bali Puspadi, do a lot of discussion and FGD especially with stakeholders who really understand will disability in Buleleng Regency. So was able to produce a law that is strong and capable of answering the needs of persons with disability Buleleng in Regency. 
Figure 3. Academin Script Arrangement

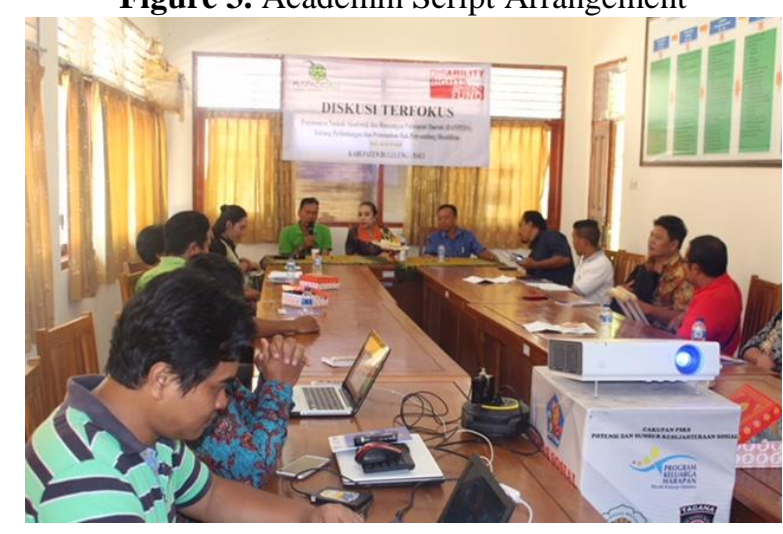

Figure 3 into one of the evidence that in designing an academic manuscript, Puspadi Bali discussion theory. Figure 3 is a discussion conducted by Puspadi Bali in the Regency of Buleleng in 2016. It also showed that in designing the academic texts into a local regulations require a long time to be able to produce regulations that can answer the needs of persons with disability. It not only takes a long time to do some discussion, to produce a law that can answer the needs of the disabled, disability, Puspadi Bali undertook to invite persons with disability in the discussion of the matter. clearly visible in Figure 11 above.

Top of liveliness in Bali Puspadi disabilities disability policy advocate through the birth of a policy, Puspadi Bali becomes a non governmet organizationI (NGO) the year 2014 in Bali given by Dunas Social Bali.

\section{Conclusion}

Disability often become minorities in society. This state of affairs makes this disability have an impact on the fulfilment of the needs and rights of persons with disability by the Government. The needs of persons with disability is often not seen by the Government. Whereas persons with disability have the right to fulfilment and equal rights with society in General. In the city of Denpasar, which is the administrative center of the region of Bali himself was, the needs of persons with disability is not fulfilled to the maximum. This can be easily seen. Even though the Government should provide the fulfilment of equal rights for persons with disability to be able to feel the public facilities.

Satisfy the needs of the disabled, disability rights up to government level is inseparable from the existence of non-governmental organizations (NGOs). NGO non governmental institution has great influence in a decision publicly. Non-governmental organizations (NGOs) Concerned with disabilities disability can help so that the needs and rights of persons with disability in terakomodasi Government policy through the stages of the public policy advocacy. Which policy advocacy is advocacy efforts (escort) programmatically against the plan of attitudes, action plan or plan decisions, plan program or regulatory plan designed by the Government to do or not to do so in accordance with the interests of the community. Policy advocacy by non-governmental organizations (NGOs) Care Disability will be able to encourage the fulfilment of the rights of persons with disability through a policy of people with disability. The results showed that the non-governmental organization (NGO) Care 
Disability i.e. Puspadi Bali has been able to be a part of the policy advocacy disability. It can be seen through some legal disability who successfully started to become a local regulations that have the force of law. It's just a policy that successfully generated by the Puspadi present in Bali Province and also the Buleleng Regency not yet come to the city of Denpasar. However, many things have been done by Puspadi Bali to initiation of academic texts that would later become a legal disability in the city of Denpasar.

\section{References}

[1] Kementrian Kesehatan RI.: Situasi Penyandang Disabilitas, Buletin Jendela Data dan Informasi Kesehatan Semester II. (2014)

[2] Rotinsulu, M.: Hidup berdampingan dengan Penyandang Disabilitas. Perspektif Baru, (2013)

[3] Rizani, A.: Optimalisasi Peran Advokasi dalam Mempengaruhi Kebijakan Publik. Kompasiana. (2011)

[4] Mariana, D.: Partisipasi Masyarakat dalam Proses Kebijakan. Cosmogov. Vol. 1(2) (2015)

[5] "Informan DN 1. Lidya Santriani (Penyandang Disabilitas Tuna Netra)"

[6] "Informan DN 2. I Gusti Ngurah Gede"

[7] "Informan LSM 2. Bapak Latra (Direktur Puspadi Bali)"

[8] "Informan LSM 3. Mba X (Staff Kaki Palsu)"

[9] Jannah, M.: Model Advokasi LSM Mitra Wanita Pekerja Rumahan Indonesia (MWPRI) (Studi Advokasi Kebijakan dalam Peningkatan Kesejahteraan Perempuan Pekerja Rumahan di Kota Malang). Thesis. Universitas Brawijaya (2017)

[10] Nugroho, R.: Policy Making Mengubah Negara Biasa Menjadi Negara Berprestasi. PT Elex Media Komputindo, Jakarta (2015)

[11] Sugiyono. Metode Penelitian Kuantitatif Kualitatif dan R\&D. Alfabeta, Bandung (2009)

[12] Suharto, E.: Pekerjaan Sosial di Dunia Industri. Cetakan kedua (2009)

[13] Semiawan.: Metode penelitian Kualitatif. Grasindo, Jakarta (2010)

[14] "Informan DR 1. Bapak I Wayan Kayun (Orang Tua dari Penyandang Disabilitas Tuna Rungu Vina Sulasih)"

[15] "Informan DN 1. Lidya Santriani (Penyandang Disabilitas Tuna Netra)"

[16] "Informan DN 2. I Gusti Ngurah Gede (Penyandang Disbailitas Tuna Netra)"

[17] "Informan DN 3. Putu Rediasa (Penyandang Disabilitas Tuna Netra)"

[18] "Informan DD 1. Nyoman Gede Suaryanata (Penyandang Disabilitas Tuna Daksa)"

[19] "Informan DD 2. Putu Ariyanto (Penyandang Disabilitas Tuna Daksa)"

[20] "Informan DD 3. Ni Ketut Mulastri (Penyandang Disabilitas Tuna Daksa)" 